\title{
MEMOIR
}

\section{SIDNEY JAMES PERRY}

Sidney JAmes Perry, who died on 22 September 1967, passed the greater part of his professional life outside the traditional fields of life assurance and consulting practice. When he became a member of the Stock Exchange in 1935, D. S. Savory and O. T. Falk were the only other Fellows of the Institute who had followed a similar path. He was thus one of the pioneers in a development which now absorbs the whole-time activity of some 33 Feliows and a number of those not yet fully qualified. It would be an exaggeration to give all the credit for this development to these early stockbroker-actuaries-the growth of institutional investment in Stock Exchange securities has been an important factor-but the success of Perry and those actuaries and accountants he gathered around him gave confidence and encouragement to other young actuaries when the opportunity arose for them to follow a similar course.

Perry's start was conventional enough for an actuary in those days. Born in 1888, the son of a shipping clerk, he joined the Northern Assurance in 1903 as a junior clerk at a salary of $£ 25$ per annum. As a commentary on conditions of those days, this appointment involved submitting to an examination and obtaining a recommendation from a director. In 1912, when he had passed three out of the four actuarial examinations, he accepted an appointment with the Phoenix to work as an accident department statistician, dealing largely with motor business which, even then, was giving companies many headaches. It is interesting to reflect that, had the war not intervened, he might now have been known as a pioneer in a very different field.

He completed his Fellowship in 1914, but following the outbreak of the war he joined up in September of that year. In the following year he was commissioned into the 6th City of London Rifles and went overseas as a Lewis Gun Officer. In 1916, he took part in the battle of the Somme and as a result of that action (in which his brother was killed) he was invalided home. The end of the war found him working as a temporary civil servant running a government scheme for the insurance of motor fishing vessels, and he was later established in this post. This job came to an end in 1922, slain by the Geddes axe. It was then he turned to investment and with the help of the late Sir William Elderton joined D. A. Bevan \& Company 'to stimulate gilt-edged business'. Perry's connexion with Elderton had begun in his student days when he devilled for him in some of his statistical researches. Perry appears with Elderton as joint author of two works-'A Third Study of the Statistics of Pulmonary Tuberculosis', published in 1910, and 'A Further Study of the Statistics of Pulmonary Tuberculosis', published in 1913. Because of this work, Journal editors tended to regard him as an expert on the subject and, between the wars, a number of reviews on further publications in this field appeared over his signature. His association with D. A. Bevan lasted until 1935 when, wishing to have more freedom to follow his own ideas, he joined Phillips \& Drew, at that time a small firm of stockbrokers with no institutional connexions. His methods proved successful and, as his business expanded, first among gilt-edged stocks and later into ordinary shares, he recruited other actuaries and accountants whom he took into partnership on generous terms. In 1952 he assumed control of the firm as senior partner, and when he retired from that position in 1959, he continued to take an active interest in the firm until 1966 when ill-health prevented him from making the daily journey to the City. He had the satisfaction in his lifetime of secing the firm grow into onc of the largest brokers in the London market.

Although quiet and almost retiring by nature, he was well known to his own genera- 
tion of actuaries. His small figure, practically unchanged in appearance over the past thirty years, was familiar to members of the Fellowship Club which, along with 22 other actuaries, he helped found in 1924. Later, in 1955, he was invited as doyen of the stockbroker-actuaries, to join the Actuaries Club, a distinction which he greatly valued.

Apart from the reviews mentioned above, his major contribution to actuarial literature was his paper 'On the relation between the course of wholesale prices of commodities and the market value of various classes of securities', which appeared in 1921 . He also reviewed for the Journal Lever's 'Lectures on Foreign Exchange'.

He possessed considerable gifts of exposition and could arrange facts with clarity and economy into a convincing argument, but he would never try to prove too much by figures. The unexplained had to be accepted as unexplained-a facet of the integrity which distinguished all his dealings, with people as well as with figures. On first acquaintance he tended to give the impression of being over-precise which perhaps owed something to his rationalist philosophy. But there was no doubt as to his fundamental generosity as exemplified in his dealings with his partners, in the two educational trusts which he founded and to which he devoted his personal fortune, and in his long services to Freemasonry.

D. WEAVER 